\title{
Acute lung injury inhibition by juglone in LPS induced sepsis mouse model involves Sirt1 activation
}

\author{
Qiong Hu${ }^{1}$, Chunai Yang ${ }^{2}$, Fenshuang Zheng1, Hongdan Duan¹, Yangshan Fu \\ Zhongfeng Cheng ${ }^{1 *}$ \\ ${ }^{1}$ Emergency Department, The Second People's Hospital of Kunming, Kunming, Yunnan 650204, ${ }^{2}$ Emergency Department, The \\ Second People's Hospital of Yunnan Province, Kunming, Yunnan 650021, China
}

${ }^{*}$ For correspondence: Email: chengzf222@sina.com

\begin{abstract}
Purpose: To investigate the effect of juglone on LPS induced lung injury in a mouse model and in TC 1 cell line.

Methods: Edema formation in lungs were measured by determination of lung wet/dry weight. Expressions of various proteins were assessed by western blot assay, while Sirt1 level was assessed using immunohistochemistry. Mice were randomly assigned to nine groups of 10 mice each: normal control, untreated and seven juglone treatment groups. Acute lung injury was induced in mice by injecting LPS (10 mg/kg) via intraperitoneal route (ip). The treatment groups were given 10, 20, 30, 40, 50,60 and $100 \mu \mathrm{M}$ of juglone, ip, respectively.

Results: The levels of MMP-9, IL-6, IL-1 $\beta$ and iNOS were significantly higher in acute lung injury induced mice compared than the control group $(p<0.05)$. Treatment of the mice with juglone significantly decreased LPS-induced up-regulation of inflammatory cytokines in a dose-dependent manner. The production of inflammatory cytokines was almost completely inhibited in the mice treated with $100 \mathrm{mg} / \mathrm{kg}$ dose of juglone, while treatment of the LPS-stimulated TC 1 cells with juglone upregulated the expression of Sirt1 mRNA. Down-regulation of Sirt1 expression by siRNA inhibited the effect of juglone on LPS-induced increase in inflammatory cytokine production.

Conclusion: Juglone prevents lung injury in mice via up-regulation of Sirt1 expression. Therefore, juglone might be useful for the development of a treatment strategy for lung injury.
\end{abstract}

Keywords: Inflammatory, Sirtuin, Edema, Cytokines, Lung injury, TC 1 lung alveolar epithelial cells, Sirt1

This is an Open Access article that uses a fund-ing model which does not charge readers or their institutions for access and distributed under the terms of the Creative Commons Attribution License (http://creativecommons.org/licenses/by/4.0) and the Budapest Open Access Initiative (http://www.budapestopenaccessinitiative.org/read), which permit unrestricted use, distribution, and reproduction in any medium, provided the original work is properly credited.

Tropical Journal of Pharmaceutical Research is indexed by Science Citation Index (SciSearch), Scopus, International Pharmaceutical Abstract, Chemical Abstracts, Embase, Index Copernicus, EBSCO, African Index Medicus, JournalSeek, Journal Citation Reports/Science Edition, Directory of Open Access Journals (DOAJ), African Journal Online, Bioline International, Open-J-Gate and Pharmacy Abstracts

\section{INTRODUCTION}

Acute lung injury is generally a complicated stage of sepsis leading to the dysfunction of pulmonary tissues and has more than $50 \%$ mortality rate [1]. Microbial infection induces inflammatory reactions which is accompanied by the development of sepsis resulting in the death of ill and weak patients [2,3]. The lipopolysaccharide (LPS) produced by the gram-negative bacteria causes sepsis on administration to the animals and is used for 
establishment of acute lung injury animal models in various studies $[4,5]$. In mice LPS administration has been found to initiate inflammatory reactions which were followed by the lung injury [6].

Sirtuin 1 (Sirt1) is a member of histone deacetylase family and is present in mammals as a homolog of Sir2. Studies have shown that Sirt1 is associated with the regulation of various pathophysiological processes in the organisms like inhibition of inflammation by mediating the production of proinflammatory factors $[7,8]$. Targeting Sirt1 gene expression by silencer (si)RNA promotes the secretion of cytokines and its activation suppresses the level of TNF- $\alpha$, monocyte chemo-attractant protein-1 and IL-8 [9]. The activation of Sirt1 by the natural products like resveratrol causes inhibition of inflammation and plays important role in the treatment of inflammation associated disorders [10]. Activation of Sirt1 has immense importance for the treatment of inflammatory diseases through suppression of cytokine release [11].

Juglone is isolated from various parts of the plants belonging to Juglandaceae family and it suppresses growth of many plants. It is generally used for colouring of food products and in cosmetics. The biological properties of juglone include oxidative stress induction [12] and downregulation of peptidyl-prolyl isomerase Pin1 [13]. The present study investigated the role of juglone in inhibition of acute lung injury caused by LPS in the mice.

\section{EXPERIMENTAL}

\section{Cell line and culture}

TC-1 mice lung alveolar epithelial cells was supplied by the Cell Bank, Chinese Academy of Sciences and were cultured in Dulbecco's Modified Eagle's Medium. The medium was mixed with antibiotics [penicillin $(100 \mathrm{U} / \mathrm{mL})$ and streptomycin $(100 \mathrm{mg} / \mathrm{mL})]$ and fetal bovine serum $(10 \%)$. The culture of cells was carried out at $37^{\circ} \mathrm{C}$ in an incubator under humidified atmosphere with $5 \% \quad \mathrm{CO}_{2}$. The cells were incubated with $100 \mathrm{ng} / \mathrm{mL}$ of LPS for $24 \mathrm{~h}$ at 37 ${ }^{\circ} \mathrm{C}$. At $2 \mathrm{~h}$ of LPS addition, 10, 20, 30, 40, 50, 60 and $100 \mu \mathrm{M}$ of juglone were added to the plates and incubated for another16 $\mathrm{h}$.

\section{Animals}

The male mice (weight 260-290 g) ninety in number were obtained from the Beijing Institute of Cardiopulmonary Vascular Disease, Beijing Anzhen Hospital (Beijing, China). All the mice were placed in sterilized and pathogen-free conditions in the Animal Care Centre, Beijing Institute of Cardiopulmonary Vascular Disease, Beijing (Beijing, China). The mice were exposed to $12 \mathrm{~h}$ day and night cycles and provided free access to feed and water. The study approval (no. BU/17/008) was obtained from the Ethics Committee of the Peoples Hospital Yunnan, China [14].

\section{Treatment strategy}

The mice were randomly assigned to nine groups of 10 mice each: normal control, untreated and seven juglone treatment groups. Acute lung injury was established in mice by injecting 10 $\mathrm{mg} / \mathrm{kg}$ dose LPS through intraperitoneal route. After $1 \mathrm{~h}$ of LPS injection, the mice in treatment groups were given 10, 20, 30, 40, 50, 60 and 100 $\mu \mathrm{M}$ of juglone intraperitoneally. The mice were sacrificed at $16 \mathrm{~h}$ of juglone injection by isoflurane anaesthesia.

\section{SIRT1 siRNA targeting}

The primer sequences of siRNA which were employed for silencing the expression of used SIRT1 were as follows: forward, 5'-ACUUUGCUGUAACCCUGUA(dTdT)-3' and backward, 5'-UACAGGGUUACAGCAAAGU (dTdT)-3'. The cells were administered siRNA at $0.62 \mu \mathrm{g} / 2 \times 10^{5}$ cells.

\section{Determination of lung wet/dry weight (W/D) ratio}

Five mice from each group were sacrificed at 16 $\mathrm{h}$ of juglone injection by isoflurane anaesthesia. The lungs from the mice were excised to record the wet weight. The mice lungs were then dried for 10 min using a microwave at a power of 200 $\mathrm{W}$ to measure the dry weight for determination of W/D ratio.

\section{Sirt1 immunohistochemistry}

Five mice from each group were sacrificed following juglone treatment using isoflurane anaesthesia. The right lungs were excised, subjected to fixing with buffered formaldehyde (3 $\%)$ and subsequently embedded in paraffin. The paraffin embedded lungs were sliced into thin sections of $2 \mu \mathrm{m}$ thickness and then stained with hematoxylin and eosin. The sections were deparaffined using xylene followed by ethyl alcohol rehydration. Then sections were treated with hydrogen peroxide for $10 \mathrm{~min}$ to quench the activity of endogenous peroxidase. After blocking the sections for $1.5 \mathrm{~h}$ with $1 \% \mathrm{BSA}$, the tissues were incubated at $4^{\circ} \mathrm{C}$ for $24 \mathrm{~h}$ with anti-Sirt1 
monoclonal antibody. The tissues were washed with PBS and then incubated for 50 min with horseradish peroxidase-labeled secondary antibody for determination Sirt1 expression. The slides were stained with diaminobenzidine tetrahydrochloride followed by hematoxylin counterstaining. The tissue sections were examined by three pathologists independently under a microscope and images were captured.

\section{Reverse transcription-quantitative PCR (RT-qPCR)}

TRIzol reagent (Invitrogen; Thermo Fisher Scientific, Inc.) was used for the isolation of total RNA in accordance with the manufacturer's protocol. The first-strand cDNA synthesis was carried out by ProSTARt First Strand RT-PCR kit (Fermentas; Thermo Fisher Scientific, Inc.). qPCR kit (OriGene Technologies, Inc., Rockville, MD, USA) was used for the RT-PCR on $20 \mu \mathrm{L}$ reaction mixture and involved 40 cycles: denaturation at $93{ }^{\circ} \mathrm{C}$ for $20 \mathrm{~s}$, annealing at $58{ }^{\circ} \mathrm{C}$ for $18 \mathrm{~s}$ and extension at $70{ }^{\circ} \mathrm{C}$ at $35 \mathrm{~s}$. The mixture used for RT-PCR consisted of $10 \mu \mathrm{M}$ of primer, $2 \mu \mathrm{L}$ of $2 x$ QuantiTect SYBR Green RT-PCR Master Mix, $10 \mu \mathrm{L}$ QuantiTect reverse transcriptase mix and $8 \mu \mathrm{L}$ nuclease-free water. The reactions were carried out three times using GAPDH as control. The following primer sequences used were:

MMP-9: forward 5'-TGT ACC GCT ATG GTT ACA CTC G-3', reverse 5'-GC CCA GAG ATT TCG ACT C-3'; iNOS: forward 5'-TTC CAC CTG GGG TTC TTG-3', reverse 5'-GCT CAA GAG TCG GGG AAG TA-3'; IL-1ß: forward5'-CTA TGT CTT GCC CGT GGA G-3',

Reverse 5'-CAT CAT CCC ACG AGT CAC A-3'; IL-6: forward5'-CTC CGC AAG AGA CTT CCA G-3', reverse5'-CTC CTC TCC GGA CTT GTG A-3'; Sirt1: forward5'-TGC ACG ACG AAG ACG ACG AC-3'; reverse5'GGT TAT CTC GGT ACC CAA TCG-3'

\section{Western blot analysis}

The TC- 1 cells at $2 \times 10^{6}$ cells per well density in 6-well plates were exposed to LPS and then treated with juglone. The cells were lysed on treatment with radioimmunoprecipitation assay buffer (Wuhan Boster Biological Technology, Ltd.). Protein concentration in the lysate was measured using bicinchoninic acid extraction kit (Wuhan Boster Biological Technology, Ltd.) in accordance with the manual procedure. The 30 $\mu \mathrm{g}$ protein samples were mixed with $2 X$ loading buffer and then denatured for $10 \mathrm{~min}$ at $100^{\circ} \mathrm{C}$. The protein resolution on SDS-PAGE was followed by transfer to the nitrocellulose filter. The membranes were subjected to incubation with primary antibodies at $4^{\circ} \mathrm{C}$ overnight. After washing with PBS the membranes were incubated for $2 \mathrm{~h}$ with secondary antibodies at room temperature. The bands were visualized using enhanced chemiluminescence stain and then auto-radiographed. The antibodies were used against MMP-9, iNOS, IL-1 $\beta$, IL-6 and Sirt1 (Santa Cruz Biotechnology, Inc., Santa Cruz, CA, USA).

\section{Statistical analysis}

The data are presented as mean \pm standard deviation (SD). Statistical differences between groups were determined using one-way analysis of variance (ANOVA) followed by Tukey's test. SPSS version 13.0 (SPSS, Inc., Chicago, IL, USA) was used for the statistical analysis, and $p$ $<0.05$ were taken to indicate statistically significant differences.

\section{RESULTS}

\section{Juglone inhibits LPS induced lung edema in mice}

The ratio of wet-dry weight of lungs was very high in the untreated mice compared to the normal control group (Figure 1). Treatment of the mice with juglone caused a dose dependent reduction in LPS induced increase in wet-dry lung weight. The suppression of LPS induced increase in wet-dry lung weight was significant from $10 \mathrm{mg} / \mathrm{kg}$ and the effect of LPS was almost completely inhibited at $100 \mathrm{mg} / \mathrm{kg}$. These results suggest that juglone inhibits edema since accumulation of water is the characteristic feature of lung edema.

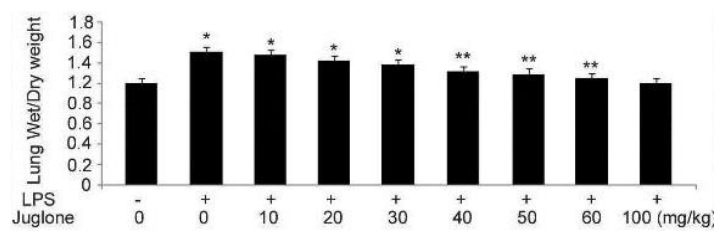

Figure 1: Effect of juglone on pulmonary edema in mice. The effect of juglone on LPS induced edema in mice was determined at 10,20,30,40,50, 60 and 100 $\mathrm{mg} / \mathrm{kg}$. Juglone was injected to mice at $2 \mathrm{~h}$ of LPS administration through intraperitoneal route; ${ }^{*} p<0.05$ and ${ }^{* *} p<0.01$ vs. untreated group

\section{Juglone prevents LPS induced pathological changes in mice}

Administration of LPS leads to a markedly higher accumulation of inflammatory cells especially neutrophils in the mice pulmonary tissues (Figure 
2). Moreover, the lungs of LPS administered mice showed inflammation and thickened septal lining when compared to the normal control group. The inflammatory cell accumulation as well thickening of the septal lining were prevented in LPS injected mice on treatment with juglone. However, the preventive effect of juglone on LPS induced pathological changes in mice tissues was dose dependent. The effect of LPS was completely prevented in the mice treated with $100 \mathrm{mg} / \mathrm{kg}$ of juglone.

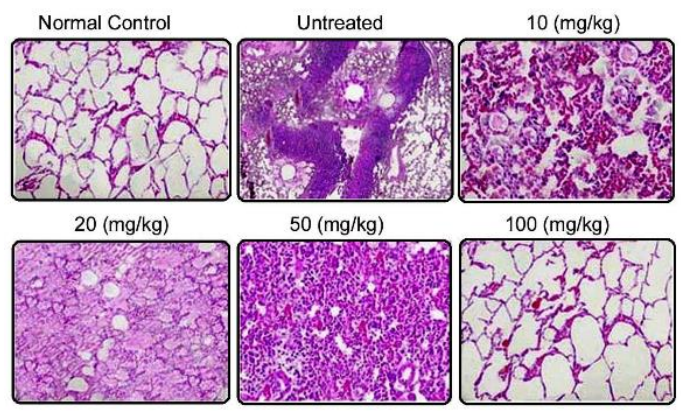

Figure 2: Effect of juglone on LPS-induced Sirt1 expression in mice. LPS-injected mice were treated with $10,20,50$ and $100 \mathrm{mg} / \mathrm{kg}$ doses of juglone after 2 $h$ of LPS injection. H\&E staining was used for assessment of histopathological alterations in lung tissues. Magnification, x200

\section{Juglone upregulates Sirt1 expression in LPS administered mice}

Western blot and immunohistochemistry assays were used to determine changes in Sirt1 expression in LPS administered mice on treatment with juglone (Figure 3). Western blotting showed that Sirt1 protein level was markedly suppressed in the LPS administered mice compared to the control group (Figure $3 \mathrm{~A}$ ). Treatment of the LPS injected mice with juglone caused increase in the level of Sirt1 protein. Immunohistochemical analysis also confirmed that juglone treatment of the LPS injected mice lead to a marked increase in the level of Sirt1 expression (Figure $3 \mathrm{~B}$ ). Juglone treatment caused a significant increase in Sirt1 expression from $10 \mathrm{mg} / \mathrm{kg}$ and the up-regulatory effect was maximum at $100 \mathrm{mg} / \mathrm{kg}$.

Effect of juglone on MMP-9 overexpression and inflammatory factor production in LPS injected mice

In LPS injected mice the levels of MMP-9, iNOS, $\mathrm{IL}-1 \beta$ and IL- 6 cytokines was markedly higher in the lung tissues, compared to normal control group (Figure 4). Treatment of the LPS injected mice with juglone caused marked suppressions in the levels of MMP-9, iNOS, IL-1 $1 \beta$ and IL-6 proteins in lung tissues.

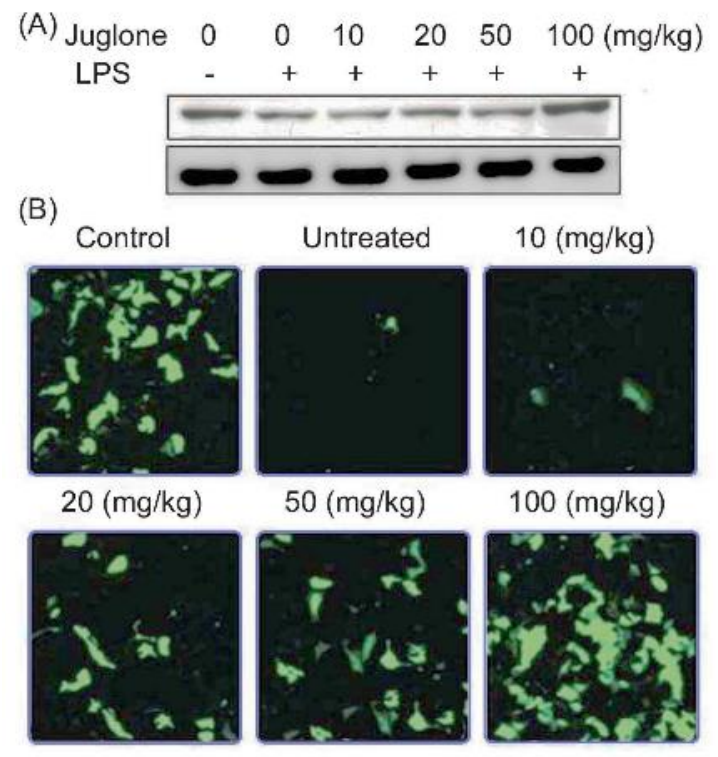

Figure 3: Effect of juglone on Sirt1 expression in LPS injected mice. LPS-injected mice were treated with 10 to $100 \mathrm{mg} / \mathrm{kg}$ of juglone after $2 \mathrm{~h}$ of LPS injection intraperitoneally. Changes in Sirt1 level in mice pulmonary tissues were determined using western blotting; ${ }^{*} p<0.05$ and ${ }^{* *} p<0.01$ vs. untreated group

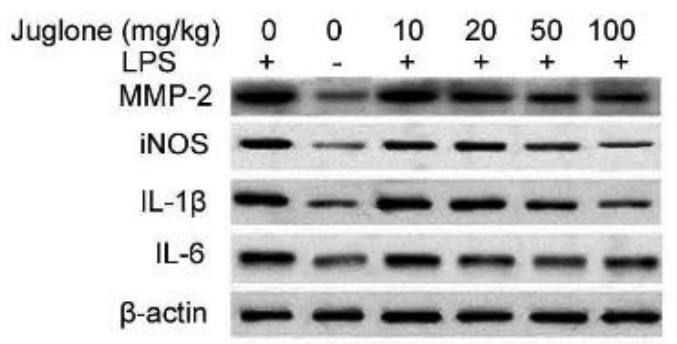

Figure 4: Effect of juglone on inflammatory cytokines in mice. Western blotting was employed to determine the levels of MMP-9, iNOS, IL- $1 \beta$ and IL- 6 in mice lung tissues after juglone treatment

\section{Juglone suppressed overexpression of MMP-9 and inflammatory factor in TC-1 cells exposed to LPS}

The western blot data showed higher level of MMP-9, iNOS, IL-1 $\beta$ and IL-6 cytokines in LPS exposed TC-1 cells (Figure 5). In the LPS injected mice treatment with $10,20,30,40,50$, 60 and $100 \mu \mathrm{M}$ concentrations of juglone caused a concentration-based suppression in MMP-9, iNOS, IL-1 $\beta$ and IL- 6 protein levels. The LPS induced up-regulation of inflammatory proteins was completely inhibited by juglone at $100 \mu \mathrm{M}$. 


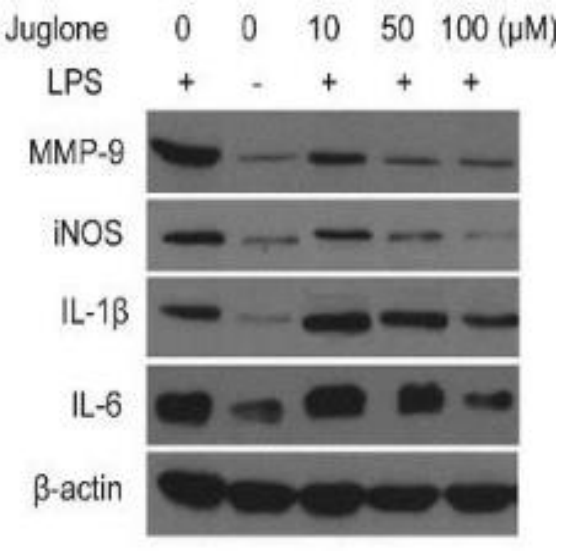

Figure 5: Down-regulation of LPS-induced inflammatory molecules by juglone in TC-1 cells. The levels of MMP-9, iNOS, IL-1 $1 \beta$ and IL- 6 in TC- 1 cells on juglone treatment were analysed at $24 \mathrm{~h}$ of LPS exposure using western blotting

\section{Inhibition of inflammatory factors by juglone involve Sirt1 downregulation}

In TC-1 cells the Sirt1 expression was inhibited by siRNA at $48 \mathrm{~h}$ compared to the control cells (Figure 6). There were no significant changes in the levels of MMP-9, iNOS, IL- $1 \beta$ and IL-6 in TC-1 cells exposed to siRNA on treatment with juglone. These results shown that juglone inhibits production of inflammatory molecules through up-regulation of Sirt1 gene.
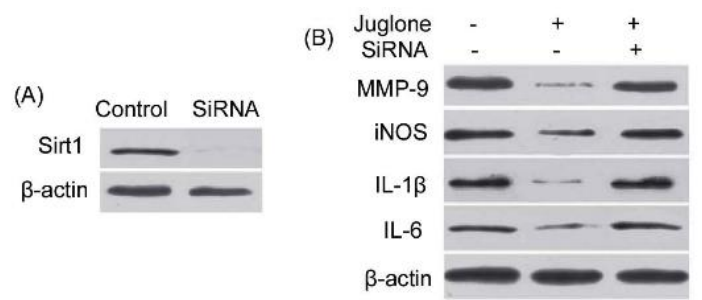

Figure 6: Effect of Sirt1-siRNA on inflammatory cytokines in LPS administered TC-1 cells. (A) Effect of Sirt1-siRNA on Sirt1 level was assessed using western blot assay. (B) Effect of juglone on MMP-9, iNOS, IL-1 $\beta$ and IL- 6 levels in TC- 1 cells treated with transfected with Sirt1-siRNA

\section{DISCUSSION}

The present study demonstrated that juglone treatment of the LPS injected mice suppressed edema development, accumulation of neutrophils and thickening of septal lining in pulmonary tissues. The therapeutic effect of juglone on lung injury involved up-regulation of Sirt1 expression and down-regulation of inflammatory cytokine.

Acute lung injury is developed commonly in the sepsis patients. Lipopolysaccharide, a bacterial endotoxin induces lung injury and therefore has been used for the establishment of acute lung injury animal models [15-17]. It is reported that preparation of acute lung injury mice model requires slightly higher doses since they are more resistant to LPS infection compared to other animals [18]. The release of proinflammatory cytokines in a systemic manner in humans leads to a syndrome known as systemic inflammatory response syndrome and this syndrome indicates the percentage of people who are prone to the development of acute lung injury $[7,19]$.

Lipopolysaccharide injection into the mice promotes pro-inflammatory cytokine release leading to injury followed by lung dysfunction. Lipopolysaccharide injection to the mice has been found to develop edema after $2 \mathrm{~h}$ of administration which gradually increases and assumes maximum size at $6 \mathrm{~h}$ [6]. Then edema starts decreasing gradually by losing the water content [6]. Lung edema is the characteristic feature of acute lung injury and is generally determined by measuring the pulmonary water content [20]. In the present study LPS administration to mice caused development of edema which was evident by markedly higher ratio of wet-dry lung weight. In the present study formation of lung edema in mice by LPS administration was suppressed effectively on treatment with juglone. The ratio of wet/dry lung weight in the LPS injected mice was also significantly reduced in mice on treatment with juglone. There was a markedly higher accumulation of inflammatory cells, especially neutrophils in the mice pulmonary tissues administered using LPS. The pulmonary tissues showed inflammation and septal lining was thickened in LPS administered mice. However, juglone treatment of LPS administered rats prevented neutrophil accumulation and thickening of the septal lining.

The level of Sirt1 is suppressed in the pulmonary tissues on administration with LPS or by inflammation [21,22]. Up-regulation of Sirt1 expression has been found to exhibit therapeutic effect on acute lung injury [20]. In the present study Sirt1 expression was suppressed markedly in the mice on administration of LPS. Juglone treatment of the LPS administered mice and TC1 cells promoted Sirt1 protein expression. The injury development in mice and TC-1 cells by LPS administration has been found to be associated with the promotion of inflammatory factor release [14]. In the present study overproduction of inflammatory cytokines, MMP-9, iNOS, IL-1 $\beta$ and IL-6 was markedly promoted in mice and $\mathrm{TC}-1$ cells on exposure to 
LPS. However, juglone treatment of the mice as well as TC-1 cells significantly suppressed the LPS mediated overproduction of MMP-9, iNOS, IL-1 $\beta$ and IL-6.

\section{CONCLUSION}

Juglone prevents acute lung injury development in mice by LPS administration by inhibition of Sirt1 expression and release of inflammatory cytokines. Moreover, treatment of mice with juglone suppresses pulmonary edema, neutrophil accumulation and tissue inflammation. Therefore, juglone may be a therapeutic agent for the treatment of acute lung injury, but further studies are needed to ascertain this.

\section{DECLARATIONS}

\section{Conflict of interest}

No conflict of interest is associated with this work.

\section{Contribution of authors}

We declare that this work was done by the authors named in this article and all liabilities pertaining to claims relating to the content of this article will be borne by the authors. Zhongfeng Cheng designed the study and wrote the manuscript. Chunai Yang, Qiong Hu, Fenshuang Zheng, Hongdan Duan and Yangshan Fu performed the experimental work. Chunai Yang, Qiong $\mathrm{Hu}$ and Fenshuang Zheng carried out the literature study. Hongdan Duan and Yangshan Fu performed literature survey and analyzed the data. The research article was thoroughly read by all the authors before communication for the consideration of publication.

\section{Open Access}

This is an Open Access article that uses a funding model which does not charge readers or their institutions for access and distributed under the terms of the Creative Commons Attribution License (http://creativecommons.org/licenses/by/ 4.0) and the Budapest Open Access Initiative (http://www.budapestopenaccessinitiative.org/rea d), which permit unrestricted use, distribution, and reproduction in any medium, provided the original work is properly credited.

\section{REFERENCES}

1. Herridge MS, Cheung AM, Tansey CM, Matte-Martyn A, Diaz-Granados N, Al-Saidi F, Cooper AB, Guest CB,
Mazer CD, Mehta S, et al.One year outcomes in survivors of the acute respiratory distress syndrome. $N$ Engl J Med 2003; 348: 683693.

2. Lee WL, Slutsky AS. Sepsis and endothelial permeability. N Engl J Med 2010; 363: 689691.

3. Hotchkiss RS, Karl IE. The pathophysiology and treatment of sepsis. N Engl J Med 2003; 348: 138150.

4. Chung YJ, Jarvis B, Pestka J. Modulation of lipopolysaccharide-induced proinflammatory cytokine production by satratoxins and other macrocyclic trichothecenes in the murine macrophage. J Toxicol Environ Health A2003; 66: 379391.

5. Bucher $M$, Taeger $K$. Endothelin receptor gene expression in rat endotoxemia. Intensive Care Med 2002; 28: 642647.

6. Rojas $M$, Woods $C R$, Mora $A L, X u J$, Brigham $K L$. Endotoxin induced lung injury in mice: structural, functional and biochemical responses. Am J Physiol Lung Cell Mol Physiol 2005; 288: L333 L341.

7. Howitz KT, Bitterman KJ, Cohen HY, Lamming DW, Lavu $S$, Wood JG, Zipkin RE, Chung P, Kisielewski A, Zhang $L L$, et al. Small molecule activators of sirtuins extend Saccharomyces cerevisiae lifespan. Nature 2003; 425: 191196.

8. Kojima $K$, Ohhashi $R$, Fujita $Y$, Hamada $N$, Akao $Y$, Nozawa $Y$, Deguchi T, Ito M.A role for SIRT1 in cell growth and chemoresistance in prostate cancer PC3 and DU145 cells. Biochem Biophys Res Commun 2008; 373: 423428.

9. Yang SR, Wright J, Bauter M, Seweryniak K, Kode A, Rahman I. Sirtuin regulates cigarette smoke induced proinflammatory mediator release via RelA/p65 NF kарраB in macrophages in vitro and in rat lungs in vivo: implications for chronic inflammation and aging. Am J Physiol Lung Cell Mol Physiol 2007; 292: L567 L576.

10. Knobloch J, Sibbing B, Jungck D, Lin Y, Urban $K$, Stoelben E, Strauch J, Koch A. Resveratrol impairs the release of steroid resistant inflammatory cytokines from human airway smooth muscle cells in chronic obstructive pulmonary disease. J Pharmacol Exp Ther 2010; 335: 788798.

11. Olholm J, Paulsen SK, Cullberg KB, Richelsen $B$, Pedersen SB. Antiinflammatory effect of resveratrol on adipokine expression and secretion in human adipose tissue explants. Int J Obes (Lond) 2010; 34: 15461553.

12. Segura-Aguilar J, Jonsson K, Tidefelt $U$, Paul C. The cytotoxic effects of 5-OH-1,4-naphthoquinone and 5,8diOH-1,4-naphthoquinone on doxorubicin-resistant human leukemia cells (HL-60). Leukemia Res 1992; 16 : 631-637.

13. Reese S, Vidyasagar A, Jacobson L, Acun Z, Esnault S, Hullett D, Malter JS, Djamali A. The Pin 1 inhibitor juglone attenuates kidney fibrogenesis via Pin 1independent mechanisms in the unilateral ureteral occlusion model. Fibrogenesis Tissue Repair 2010; 3: 1.

14. Zhong J-M, Wu S-Y, Bai J, Guo Q, Tao J, Chen H, Zhao $N-W$, Zhao Z, Fu $H$. Antidepressant effect of geranylgeranylacetone in a chronic mild stress model of

Trop J Pharm Res, May 2020; 19(5): 1006 
depression and its possible mechanism. Expt. Ther. Med 2012; 4: 627-632.

15. Matsuda N, Hattori $Y$, Takahashi $Y$, Nishihira J, Jesmin $S$, Kobayashi M, Gando S. Therapeutic effect of in vivo transfection of transcription factor decoy to NF kappaB on septic lung in mice. Am J Physiol Lung Cell Mol Physiol 2004; 287: L1248 L1255.

16. Oshikawa K, Sugiyama Y. Gene expression of Toll like receptors and associated molecules induced by inflammatory stimuli in the primary alveolar macrophage. Biochem Biophys Res Commun 2003; 305: 649655.

17. Yull FE, Han W, Jansen ED, Everhart MB, Sadikot RT, Christman JW, Blackwell TS. Bioluminescent detection of endotoxin effects on HIV 1 LTR driven transcription in vivo. J Histochem Cytochem 2003; 51: 741749.

18. Pietrantoni C, Minai OA, Yu NC, Maurer JR, Haug MT 3rd, Mehta AC, Arroliga AC. Respiratory failure and sepsis are the major causes of ICU admissions and mortality in survivors of lung transplants. Chest 2003; 123: 504509.

19. Takala A, Nupponen I, Kylänpää-Bäck ML, Repo $H$. Markers of inflammation in sepsis. Ann Med 2002; 34: 614623.

20. Li T, Zhang J, Feng J, Li Q, Wu L, Ye Q, Sun J, Lin Y, Zhang M, Huang R, et al. Mol. Med. Reports 2013; 7: 1889-1895.

21. Lee SJ, Kim MM. Resveratrol with antioxidant activity inhibits matrix metalloproteinase via modulation of SIRT1 in human fibrosarcoma cells. Life Sci 2011; 88: 465472.

22. Niederer $F$, Ospelt $C$, Brentano $F$, Michael OH, Renate $E$ G, Steffen G, Michael D, Diego K. SIRT1 overexpression in the rheumatoid arthritis synovium contributes to proinflammatory cytokine production and apoptosis resistance. Ann Rheum Dis 2011; 70: 1866 1873. 